\title{
RURAL SPACE GOVERNANCE IN EXTREMADURA (SW SPAIN). ANALYSIS OF THE LEADER APPROACH
}

\author{
Gema Cárdenas Alonso, Ana Nieto Masot ${ }^{1}$
}

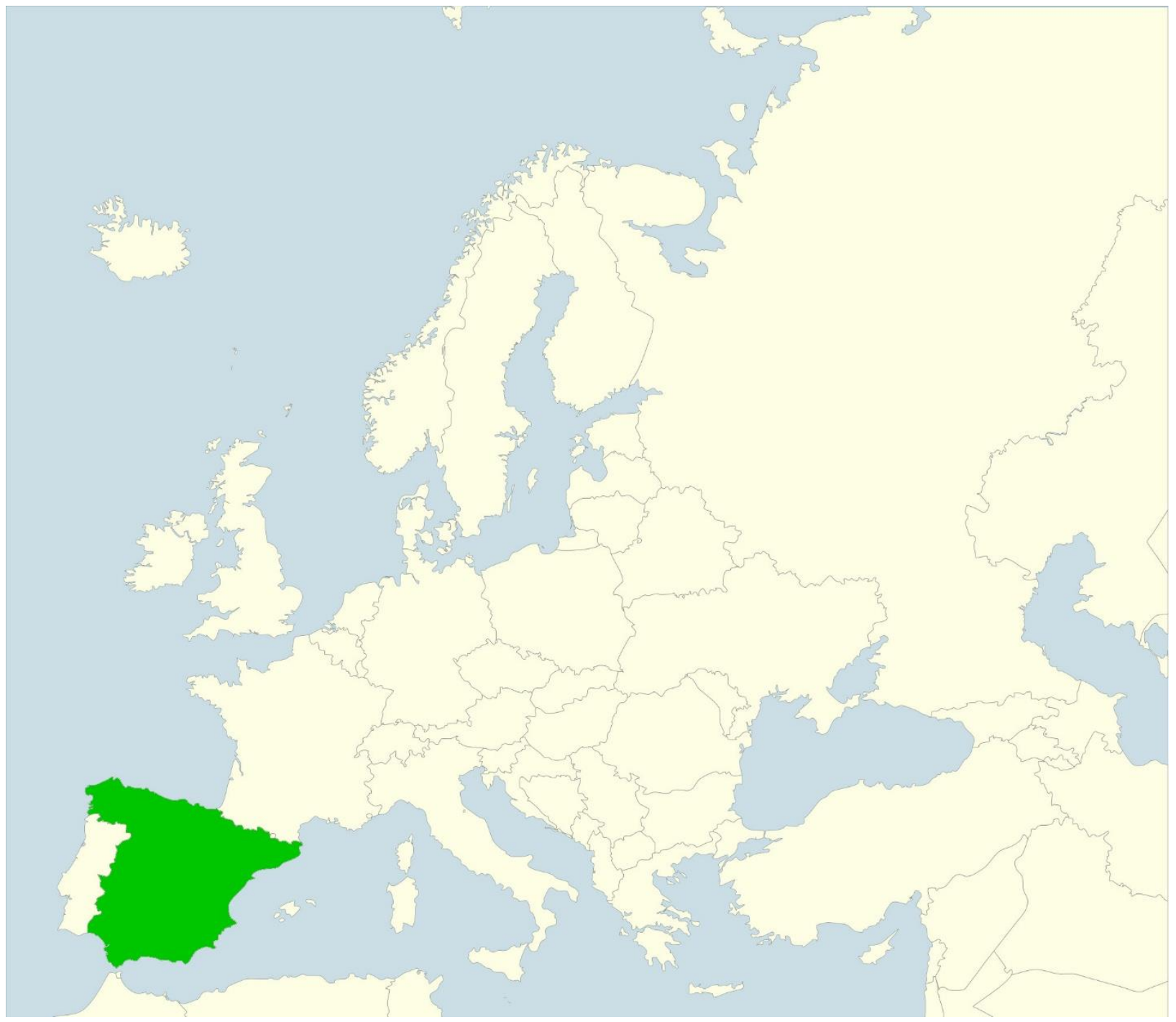

${ }^{1}$ Prof. Gema Cárdenas Alonso, Ph.D., email: gemacardenas@unex.es, ORCID: 0000-0002-4977-8599; Ass. Prof. Ana Nieto Masot, Ph.D., email: ananieto@unex.es, ORCID: 0000-0001-9301-8637, University of Extremadura Badajoz. 
Abstract: The LAGs (Local Action Groups) are in charge of designing the development strategy under the LEADER Approach for their areas of action, as well as managing European aid for Rural Development in order to promote new economic activities with which generate progress and alleviate the demographic and socioeconomic problems of its most depressed municipalities. Thus, in this paper the qualitative analysis of LEADER in Extremadura (SW Spain) in the 2007-2013 programming period is presented through the results of a questionnaire to the technical staffs of the 24 LAGs in order to complement the various previous quantitative studies and to know the opinion of essential actors in the rural development processes. During the 2007-2013 period (with the EAFRD as European Fund to finance rural development aids) LAGs have faced great bureaucratic and administrative burdens, which adds to the difficult economic situation experienced in recent years. This has hindered the true labor of these partnerships, that is, to revitalize their territories of action in order to create socioeconomic and, consequently, demographic development.

Keywords: Governance; LEADER influence; LEADER management; Rural areas; Rural Development Program; Local Action Group

Resumen: Los GAL (Grupo de Acción Local) son los encargados de elaborar las estrategias de desarrollo de sus áreas de actuación bajo el Método LEADER, así como de la gestión de las ayudas europeas al Desarrollo Rural, con el fin de promover la creación de nuevas actividades económicas con las que generar progreso y solventar los problemas demográficos y socioeconómicos que sufren sus municipios más deprimidos. Así, en este trabajo se presenta un análisis cualitativo de LEADER en Extremadura (SO de España) en el periodo de programación 2007-2013 de los resultados obtenidos de un cuestionario realizado a los equipos técnicos de los 24 GAL con el fin de complementar a los diversos estudios cuantitativos ya existentes conociendo la opinión de actores esenciales en los procesos de desarrollo rural. Así, durante el periodo 2007-2013 (con el FEADER como fondo financiador de las ayudas al desarrollo rural), los GAL tuvieron que hacer frente a numerosos inconvenientes burocráticos y administrativos, a lo que se unieron las dificultades derivadas de la crisis económica experimentada en esos años, dificultando la verdadera labor de estos partenariados, es decir, la de revitalizar y estimular a la población de sus territorios de actuación con el fin de generar desarrollo socioeconómico $y$, consecuentemente, demográfico.

Palabras clave: Gobernanza; Influencia de LEADER; Gestión de LEADER; Áreas rurales; Programa de Desarrollo Rural; Grupo de Acción Local

\section{Introduction. Theoretical background}

In order to reduce the socio-economic and demographic problems of European rural areas and their territorial differences with respect to urban ones, the EU opted (in the early 90s) for the creation and implementation of policies, initiatives or actions aimed at to correct them. One of these actions is the one dedicated to rural development under the LEADER Approach, which works with a bottom-up methodology (Dax \& Fischer, 2018). It is a development model whose purpose is to activate the socioeconomic potential of rural areas and maintain them with an adequate demographic level through the diversification of their economic activities, the conservation of their heritage, both natural and historical, or the promotion of the use of new technologies (Alario \& Baraja, 2006; Febles Ramírez, García Rodríguez, \& Zapata Hernández, 2005). This is through the creation and implementation of projects partly financed by the European Structural Funds, national administrations (General State Administration and Regional Administration) and private actors (local population) (Nieto Masot \& Cárdenas Alonso, 2018). The LEADER Approach has always been considered as an innovative and alternative 
management model of public affairs (Buller, 2002; Kovach, 2000; Osti, 2000). This has meant the transformation and rebuilding of public action in rural development processes by the incorporation of new non-political actors related to the Administration at different decision levels (Abad Aragón, 2013, 2014; Pemán \& Jiménez, 2013), such as self-employed workers, social associations, cooperatives, etc. Therefore, the local population is involved in decisionmaking and in the design of territorial rural development strategies.

LEADER is the only European initiative that has continued to function since the 1990s, as others such as URBAN or EQUAL have disappeared. LEADER was created as a pilot project and has evolved to become an axis of action for the European Agricultural Fund for Rural Development (EAFRD) in the 2007-2013 programming period.

The Local Action Groups (LAGs) manage and execute the LEADER aids, designing and implementing the Rural Development Strategy of their territories of action. LAGs are considered as key tools in achieving sustainable development in European rural areas (Bjärstig \& Sandström, 2017) and are local government structures endowed with an organization and technical staff responsible for the implementation of rural innovation actions and projects (los Ríos-Carmenado, Cadena-Iñiguez, \& Díaz-Puente, 2011). Various authors define these public-private partnerships as "collaboration agreements in which actors from two or more spheres of society (state, economic and / or civil agents) are involved in a non-hierarchical process in search of sustainable development" (Van Huijstee, Francken, \& Leroy, 2007) or as "non-profit business organizations that aspire to improve environmental quality or the use of natural resources through jointly defined voluntary activities in decision-making processes" (Long \& Arnold, 1995). Thus, LAGs contribute to the promotion of endogenous development as a means of generating greater capacity for rural people to fight against global competition, the economic crisis or social exclusion (Ray, 1999a, 1999b; Shucksmith, 2010). In this way, LAGs have an essential strategic role in rural areas where they act for the integration and valorization of territorial resources and an important capacity to promote the participation of local communities in development processes (Grybovych \& Hafermann, 2010; Lenao \& Saarinen, 2015; Quaranta, Citro, \& Salvia, 2016). In addition, professional actors from rural areas are represented in LAGs through various governance mechanisms from the public and private spheres and volunteers, who together work in different contexts of power but towards the same objective (Shucksmith, 2000, 2004, 2010). Thus, all these actors, who form part of the LAGs, implement actions in spaces in crisis that lose population and are in danger of depopulation (especially those with less than 500 inhabitants).

Currently, the EAFRD is the European Fund that subsidizes aid for rural development under Regulation (EC) 1698/2005 for the 2007-2013 programming period and Regulation (EC) 1305/2013 for the current one, 2014-2020. During the first EAFRD period, aid was applied through four lines of action: Axis 1. Increase in the competitiveness of the agricultural and forestry sector; Axis 2. Improvement of the environment and the rural environment; Axis 3. Quality of life in rural areas and diversification of the rural economy; Axis 4. LEADER. Through this last axis, the LAGs applied the LEADER Approach as a local development strategy by zones through partnerships between the public and private sectors, also managing almost all of the submeasures of Axis 3 and one of Axis 1, in the case of Extremadura (study area of this work).

Over the years and in the successive stages, the European Commission has introduced changes to the Regulation in order to further develop its rural areas, as well as to facilitate the work of the LAGs (Cárdenas Alonso \& Nieto Masot, 2020). However, during the last Programming Period (2007-2013), these associations faced, apart from the changes in the Regulation, an important economic crisis and complex bureaucratic procedures, which really hindered their dynamic labor. Taking this into account, how have the managers of the LAGs of Extremadura (the study area of this paper) faced the design and execution of rural development strategies and programs (20072013)?

Taking into account the objectives always proposed by LEADER, the need for an evaluation of the results at a quantitative level in terms of executed projects is clear. In Spain, the regions used as study areas are diverse, such as Cantabria (Delgado Viñas, 2002; Delgado Viñas \& Fuente Royano, 2000); Castilla-La Mancha (Alfaro, 2004; Carmona García, 2013; Gómez Borja, Mondéjar Jiménez, Mondéjar Jiménez, \& Monsalve Serrano, 2006; M. Vargas-Vargas, 
Meseguer-Santamaría, Mondéjar-Jiménez, \& Mondéjar-Jiménez, 2009; Manuel Vargas-Vargas, Mondéjar-Jiménez, Mondéjar-Jiménez, \& Meseguer-Santamaría, 2009; Vargas Vargas \& Mondéjar Jiménez, 2006), Andalucía (Cejudo \& Navarro, 2009; Cortés Macías, 2001; Navarro, Cejudo, \& Maroto, 2014) and Extremadura (Nieto Masot \& Cárdenas Alonso, 2015, 2018). These are studies in which, mainly, LEADER is analyzed by presenting the territorial distribution of aid, financing by action measures, the type of promoter, the number of jobs or number of tourist accommodation created, among other indicators. In addition, generally, LEADER has been studied in orthodox research as a mere policy without taking into account the interaction dynamics and qualitative outputs between local actors and their overarching geographical, institutional, and territorial structures (Rizzo, 2013).

However, the social aspect of LEADER is undeniable (Navarro, Woods, \& Cejudo, 2015), in fact, authors such as Sáenz and Cejudo (2008) argue that the success of LEADER is more qualitative than quantitative, and Márquez et al (2005) said that its success is a mixture of both spheres. Mondéjar et al. (2007) sustain that LEADER was not born exclusively for the achievement of quantifiable economic or social objectives, but as a laboratory of ideas with which to experience innovation and transfer results, which should also be evaluated and analyzed. This has been carried out by authors such as Álvarez (1999) and Navarro et al. (2014), which have focused their studies, especially, on associative movement, social participation and innovation. Other authors analyze the social capital generated through LEADER, such as Garrido and Moyano (2002), Buciega (2012), Buciega and Esparcia (2013), Esparcia et al. (2015), Rizzo (2013), Shucksmith (2000, 2004, 2010), Zajda (2014) or Saz-Gil and Gómez-Quintero (2015). Pérez Rubio (2007) analyzed the relevance of intangibles in the processes of rural development in various regions. Therefore, as Delgado et al (1999) already stated in studies on Agenda 2000, "it is necessary to go beyond the classic evaluations that only use economically quantifiable criteria to provide additional information that allows measuring the qualitative impacts of the specific elements of this initiative".

The objective of this paper is to analyze LEADER (2007-2013) qualitatively in the Spanish region of Extremadura in order to complement the existing quantitative studies (Cárdenas Alonso \& Nieto Masot, 2017; Leco Berrocal, Pérez Díaz, \& Mateos Rodríguez, 2017; Nieto Masot \& Cárdenas Alonso, 2015, 2017a, 2018; Nieto Masot, Cárdenas Alonso, \& Costa Moreno, 2019), as well as to learn the opinions of the technical staffs of the LAGs on the operation and materialization of Rural Development Program (2007-2013) in the region. Moreover, it is intended to study intangible aspects that are part of the essence of LEADER, as well as immaterial specifities, which is practically impossible through quantitative techniques. This is possible through the preparation and analysis of a survey of the technical staffs of the 24 LAGs currently working in Extremadura. The importance of investigating LEADER in this Spanish region lies in the fact that it is still a predominantly rural region (Delgado et al., 1999; Nieto Masot et al., 2019; Sancho Comíns \& Reinoso Moreno, 2012) and the only one in Spain with its GDP below 75\% of the European average (Consejería de Medio Ambiente y Rural, 2020), as well as a beneficiary since the beginning, in the $90 \mathrm{~s}$, of the rural development aid. However, the region continues to present serious demographic and economic problems even being the recipient of these aids and other complementary policies for almost 30 years. The best results, in terms of investments through the LEADER Approach, are being experienced in the most demographically and economically developed rural areas of the region, since it is in them where more projects have been launched and with greater investments. These are the agricultural areas with irrigated land and productive dry land of vine and olive tree located around the main communication routes and urban centers, as well as the main county seats. This has caused that the areas that really need the most positive effects, both economic and social, of the rural development aid, that is, the oldest and most unpopulated areas, are left aside. These are located mainly in mountain areas and on the borders with Portugal and other autonomous communities (Nieto Masot, Cárdenas Alonso, \& Engelmo Moriche, 2020).

Hereafter, the methodology of this paper is presented, followed by Section 3 in which the results obtained are shown. Finally, Section 4 presents the discussion and conclusions. 


\section{Methodology}

\subsection{Study area}

If Extremadura is characterized by anything, it is because it is a sparsely populated territory even though it has a strategic position on the axis between the three major metropolitan areas of the Iberian Peninsula (Figure 1). Thus, Extremadura is presented in Europe as part of the interior spaces between the Atlantic and Mediterranean axes, this being a marked territory, except for the presence of Madrid and some large urban centers, by low population densities and rural dynamics.

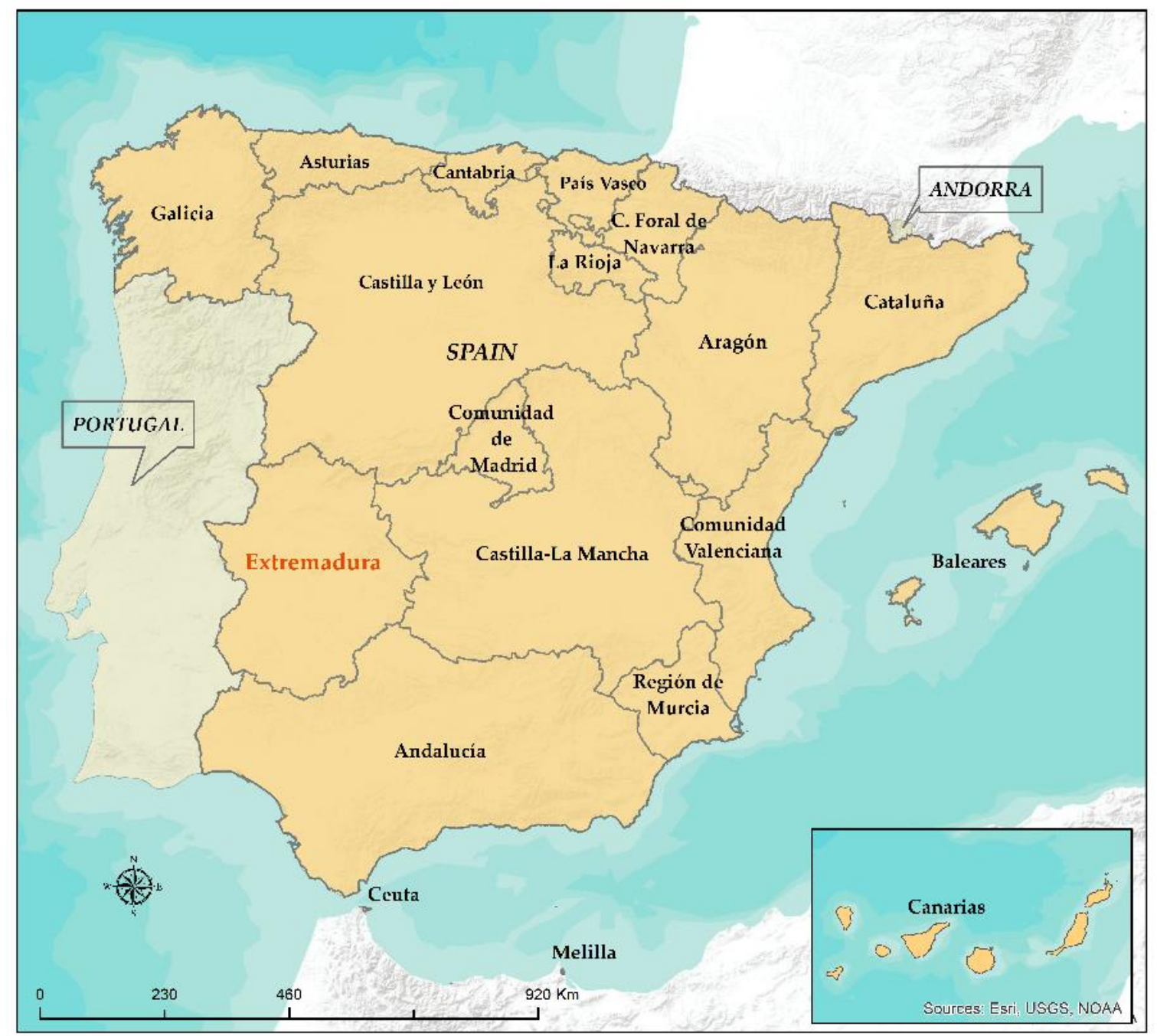

Fig 1. Peninsular framing of the territory of Extremadura, the study area. Source: Authors based on the National Cartographic Dataset.

During the last 40 years, the differences between Spanish regions have been shortened, especially thanks to the financial assistance received since Spain entered the EEC (European Economic Community) (EU (European Union) currently). However, the economic data continue to reveal a significant delay in Spain with respect to European socio-economic averages, as well as regional differences. These regional disparities are increasing again due to the current economic crisis and restrictions on public and private investments. In Spain, territorial and economic development is concentrated in traditional industrial development hubs, mainly in northern coastal regions (Cantabria, País Vasco, and Navarra) and in commercial areas of the Spanish east, especially in Catalonia. The highest urban concentrations with positive demographic variables (high birth rates and positive population growth), the highest incomes and the greatest economic, industrial and tourist activity (sun and beach, on the coast) are located in 
Madrid and its surroundings and in the coastal areas. Conversely, there is a rural Spain with increasingly lower population densities, with high aging rates and significant rural-city migrations, where the economy still depends, excessively, on agriculture and livestock, even though these activities are not very profitable. In these areas, the so-called "emptied Spain" is with abandoned municipalities, more specifically in the northern half of the plateau, in Aragón, in northern Extremadura, inland areas of Galicia, and in Asturias. There are other rural areas where various development strategies, such as LEADER, are helping to ensure that demographic and socioeconomic indicators are not excessively worrisome. This is what happens in much of Andalucía, Extremadura and Castilla-La Mancha.

The rural area in Spain covers $90 \%$ of the territory and only $20 \%$ of the Spanish population. Its population density is 19.79 inhabitants $/ \mathrm{km}^{2}$ compared to the Spanish average (92 inhabitants $/ \mathrm{km}^{2}$ ), that is, there is a large dispersion of the rural population, which hinders its possibilities of economic and demographic development, with annual constant losses of population. Furthermore, Spanish rural areas are characterized by high aging rates, high active population in the agrarian sector, high unemployment, a difficult situation of women and a significant digital gap.

In the case of Extremadura, it takes part in those regions with a less diversified and active economy such as Andalucía, Castilla-La Mancha, Castilla y León, and Galicia, and that are the Spanish rural areas. It is placed in the west of Spain with a surface area of $40,000 \mathrm{~km}^{2}$, over 1 million inhabitants spread across 388 municipalities (Figure 2), a population density of 27 inhabitants $/ \mathrm{km}^{2}$ and most of the population concentrated in the major towns (Nieto Masot \& Cárdenas Alonso, 2017a).

The strong migrations of the post-civil war have conditioned the demography of Extremadura and still the palpable consequences of the economic crisis have aggravated its situation. According to the National Statistics Institute (NSI) of Spain, between 2012 and 2016, the 17 Spanish autonomous communities have lost population, but the differential factor of Extremadura is the special aging of its rural areas, that is, practically the entire regional territory, although during that period the cities of Extremadura (Badajoz, Cáceres, Mérida and Plasencia) also lose population. The most affected spaces are those linked to the outer ring of the region that are less connected to the main axes of articulation with the outside.

From the economic point of view, the region has followed a path of convergence with the values of the whole of Spain. According to the 2000-2018 series of the Spanish Regional Accounts of the NSI, the per capita GDP of Extremadura was $63.5 \%$ of the national average in the year 2000, reaching $71 \%$ in 2010; data shows a slow increase reaching $72.8 \%$, until 2018 . In other words, the region is immersed in a dynamic of convergence but at risk from the economic crisis.

As the main socioeconomic characteristics of the region, they are still the high representation of the agrarian sector in the regional GDP (although the tertiary sector with commerce, tourism and transport is the one that generates the most employment and wealth), the high unemployment rate, reduced purchasing power, low productivity, and high public sector indebtedness. However, regarding quality of life (material living conditions, leisure, social relations, physical and personal security), Extremadura presents a similar situation to that of the rest of Spain, although, regarding the dimensions of work, health, education, governance and basic rights presents values slightly below the national average.

In this regard, taking into account physical, economic, social and demographic characteristics, in Extremadura, there are a variety of territories. On the one hand, there are areas with a good development level with adequate equipment and infrastructures, and that present an articulated, modern and competitive agro-industrial sector located in irrigated areas (Vegas del Guadiana, Campo Arañuelo and Valle del Alagón) and productive dry land of vine and olive tree (Tierra de Barros); on the other hand, there are areas far from urban centers, with little population and aging and with important deficiencies in terms of infrastructure and equipment, in which the primary sector is unable to provide the necessary income to the population due to its low competitiveness and insufficient articulation with other sectors such as agro-industry. These most disadvantaged areas are located in mountain areas (northern Extremadura) and peneplain, in the province of Cáceres (north) and in the limits of the province of Badajoz (south). Finally, there 
are intermediate areas that have good rural-urban interaction, where people complement their income from the primary sector with activities in other sectors (industry, service sector or tourism) as a consequence of the daily displacement of rural workers to the closest urban centres (Nieto Masot \& Cárdenas Alonso, 2017a, 2017b) .

Although, in recent years, increasing territorial cooperation processes that indicate a progressive operation in the network of cities, towns and counties have been detected, taking into account the characteristics described above, Extremadura faces problems such as the lack of sufficient urban centers size to be placed in the context of world-class cities and the lack of articulation and economic structure of their most disadvantaged demographic and economic areas. Moreover, some authors, such as Risco and De la Macorra (2006) and Cayetano (2006) consider that the scarce socio-economic development of the region is mainly due to the inadequate exploitation of its lands, the little productive transformation of its primary resources, the underdevelopment of infrastructures, the small population and the low demographic density.

From the point of view of Rural Development, 24 LAGs are working in Extremadura (Figure 2). They are composed by all the municipalities of the region $(98.8 \%$, with $70.9 \%$ of the population), except the cities of Badajoz, Cáceres, Mérida and Plasencia, and occupy $89.7 \%$ of the regional surface. 


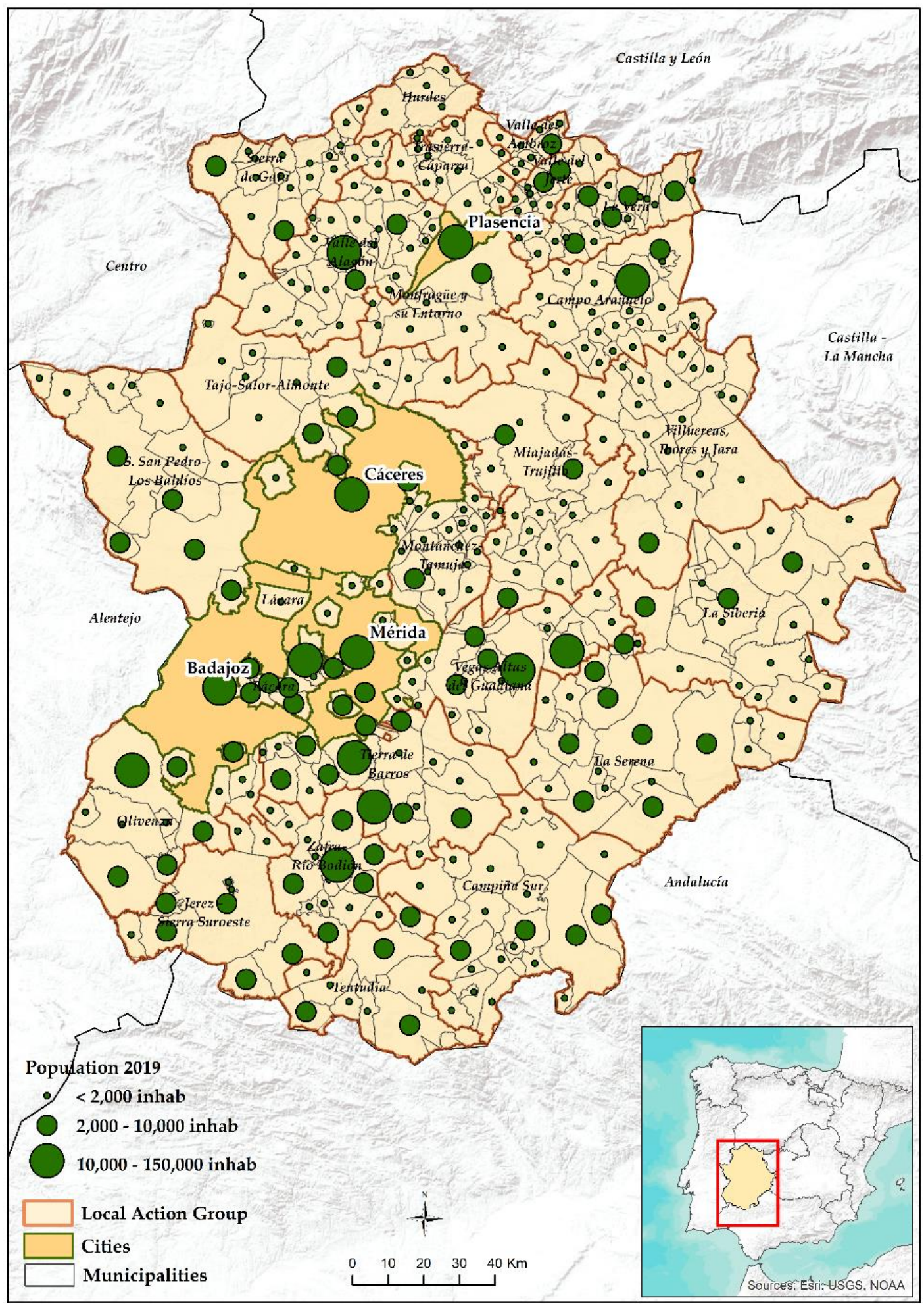

Fig 2. Local Action Groups in Extremadura and distribution of the population (2019). Source: Authors based on the National Cartographic Dataset and NSI

\subsection{Preparation of the questionnaire}

A questionnaire was prepared in order to obtain qualitative information on LEADER in Extremadura in the 2007-2013 programming period since, as Munn and Drever (1990) and Arribas (2004) affirm, its advantages are diverse:

1) A questionnaire provides standardized information, so that the respondents (the technical staffs of the 24 LAGs of Extremadura) answer the same set of questions, making it easy to compare and interpret their answers; 
2) It saves time and makes it easier to do if it is done electronically, as it allows a large number of people to be surveyed at once;

3) The respondents can answer at the most appropriate time. However, the elaboration of a questionnaire takes time and requires specific experience and previous knowledge (Lemus Martín, Castillo, Moya Morales, Padilla García, \& Ryan, 2008), which is considered as accomplished in this research.

For this reason, it was decided to carry out a self-administered structured questionnaire (with questions and possible formalized and standardized answers) through a web application, which, in addition, facilitated greater confidentiality and that respondents had the opportunity to answer frankly and sincerely. Finally, completing a self-administered online questionnaire expedited the collection and final analysis of the responses.

Although there is no consolidated theory to guide the construction of a questionnaire and the writing of questions (Foddy \& Foddy, 1994), knowledge of the study area and of the legislative and quantitative functioning of Rural Development policy in Extremadura over the last three decades has been the guideline for the construction of the questionnaire used in this study. Thus, the questionnaire consisted of 30 questions, 29 closed and 1, the last, open, in order for the interviewees to contribute their ideas or opinions they considered appropriate about the application of the LEADER Approach in Extremadura during the period 2007-2013.

In the questionnaire, three groups of questions can be identified (Table 1):

Tab 1. Characteristics of the questionnaire.

\begin{tabular}{|c|c|}
\hline \multicolumn{2}{|c|}{ CONTENT AREA: LEADER IN EXTREMADURA (2007-2013) } \\
\hline Variables & Question type \\
\hline $\begin{array}{l}\text { Age } \\
\text { Gender } \\
\text { Level of education } \\
\text { Place of residence } \\
\text { Occupation/Position in the LAG }\end{array}$ & Closed \\
\hline $\begin{array}{l}\text { THE INVOLVEMENT OF THE RESPONDENT IN LEADER } \\
\text { Participation of the respondent } \\
\text { Request for help and opinion from the local population }\end{array}$ & Closed \\
\hline $\begin{array}{l}\text { LEADER IMPACT } \\
\text { Endogenous and sustainable development } \\
\text { Economic sectors } \\
\text { Economic, social and environmental impact } \\
\text { Administrative and bureaucratic difficulties } \\
\text { Investment distribution } \\
\text { Search for promoters } \\
\text { Number and type of projects }\end{array}$ & Closed \\
\hline $\begin{array}{l}\text { IDEAS AND GENERAL OPINIONS OF THE RESPONDENT } \\
\end{array}$ & Open \\
\hline
\end{tabular}

There is a first group with demographic questions, which aim to "know" the respondents. They are designed to obtain information on variables such as age, gender, educational level or place of residence, as well as their occupation in the LAG. Secondly, there is a group with questions about the participation and involvement of the respondent in the application of LEADER in their territory of action. Finally, there is a third group with questions about the possible impact of LEADER: how LEADER has promoted endogenous and sustainable development, what sectors are the LAG most committed to, economic, social and environmental impacts, administrative and 
bureaucratic difficulties, territorial and sectoral distribution of aid, the search for promoters or the number and type of projects executed in their LAGs. The fact that, in this research, the questionnaire is only addressed to technical staff of the LAGs is justified by the fact that they are the highest executing bodies for development strategies and responsible for awarding subsidies. It is considered relevant to know the tasks carried out by technical teams of LAGs, since they are responsible for the administration of the program, the implementation of agreements adopted by the decision-making bodies and to advise promoters. In future research, the questionnaire will be addressed to beneficiaries of LEADER aids and to social and political actors to find out their perceptions and opinions on the operation of the LEADER Approach.

Thus, the questionnaire was sent to each of the 24 LAGs of Extremadura with the request to be made by all members of their technical staffs or, failing that, as many as possible.

It was taken into account that the n-optimum obtained for an estimated sample size of 72 (with an average of 3 workers per LAG), an error of $3 \%$ and a confidence level of $90 \%$, was 66 .

\subsection{Analysis of the questionnaire}

First, the answers have been descriptively analyzed, taking the total responses as a reference and calculating percentages and maximum, minimum and average trends. Thus, through descriptive analysis, information has been collected and ordered in graphs and visual media, the most representative characteristics of the data collected have been extracted, and trends in answers have been described (Fernández, Sánchez, Córdoba, \& Largo, 2002).

Afterwards, the open testimonies of all the respondents have been analyzed through the construction of a "word cloud" and a "word tree" using the NVIVO Pro 11 software. This software is designed to facilitate qualitative techniques that allow the organization, analysis and sharing of data, regardless of the method used. In this case, NVIVO Pro 11 has been used for the interest in evaluating, interpreting and explaining the social phenomenon of LEADER through the analysis of data extracted from a questionnaire. There are diverse fields of knowledge in which this type of software is used, from social sciences and education (Trigueros Cervantes, Rivera García, Moreno Doña, \& Muñoz Luna, 2016) to health care and business (Palacios Vicario, Gutiérrez García, \& Sánchez Gómez, 2013), either to analyze interviews, focus group transcripts, field notes, web pages or journal articles. The qualitative analysis tools that NVIVO Pro 11 offers are many and varied and for this study a "word cloud" or frequency of words and a "word tree" have been constructed and studied taking the information obtained thanks to an open question in which the respondents have been able to capture ideas and opinions in testimonies about the phenomenon studied. The first is a Word Frequency Search technique with which, by exact match, root word or synonyms, a word cloud is obtained. It is a query that, firstly, gives a table in which the number of repetitions of each word appears and then a visual representation of the same that make up the text of the responses where the size is greater for the words that appear more frequently. This helps to identify key concepts that can be considered as nodes or to identify the concepts that have a greater weight in the set. Regarding the second technique, the "word tree", it can be said that it derives, in part, from the first. This takes the most mentioned word or concept as a node, in such a way that it can be seen the way in which people talk about that concept and the common thread of the free and open testimonies of the respondents around the most cited word (Martín Cilleros \& Sánchez Gómez, 2016; Sarasola Sánchez-Serrano, López Meneses, \& Fernández Márquez, 2013; Vázquez Cano, López Meneses, \& Fernández Márquez, 2016).

\section{Results}

In response to the n-optimum obtained (66), the questionnaire was answered by $59.09 \%$ (39) of the sample, although at least one technician from each LAG did it, so there are answers for all of them. The percentage of participation could be identified with the degree of participation and transparency of the technical staffs of the LAGs of Extremadura. They were informed that they were requested to make a questionnaire supported by a research funded by the Government of Extremadura (PD12028, 2013). 


\subsection{Characteristics of the respondents}

$58.9 \%$ of the people who answered the questionnaire are LAG technicians, while $38.5 \%$ are managers (who assume the leadership, management and development responsibilities of the LAG). Most of them (43.6\%) are in the range of 36 to 45 years, followed by those who are 46 to 60 years old, with $38.5 \%$. The rest (17.9\%) are between 26 and 35 years old. Regarding educational level, the majority ( $82 \%)$ have higher education and the rest $(12.8 \%)$ have secondary education.

\subsection{Participation in LEADER}

In order to study the involvement of LAG technicians in the rural development processes of their municipalities, they were asked about the intensity with which they are involved in them, as $94.9 \%$ consider it high and only two people (5.13\%) very low. This is surprising considering that this is the principal function of LAG workers. In the operation of LEADER, the effort of the technicians as dynamic agents of the social and economic fabric of their territories is essential, as well as that they achieve to involve the local population in the promotion of new businesses or improvement of existing ones. This is related to the question about the frequency with which neighbors, entrepreneurs, etc., come to them to ask for advice or help about LEADER initiatives, which is, in most cases $(84.6 \%)$, very high. This shows that the technicians have the perception that a large population of the region knows that there are European aids to create businesses, improve their companies, create associations, tourist dissemination campaigns, etc. Only $15.4 \%$ consider that the population rarely comes to them to answer questions about LEADER.

\subsection{LEADER influence}

Practically all of the respondents (97.4\%) confirm that in their LAGs they have worked with a clear development strategy based, mainly (Figure 3), in the areas of Agroindustry (92.3\%), Tourism $(82 \%)$ and Heritage and Environment $(69.2 \%)$. At the same time, $66.7 \%$ of the respondents answer that they have also opted for the creation and/or improvements of activities in the services sector and for training activities that are not directly related with the previous areas.

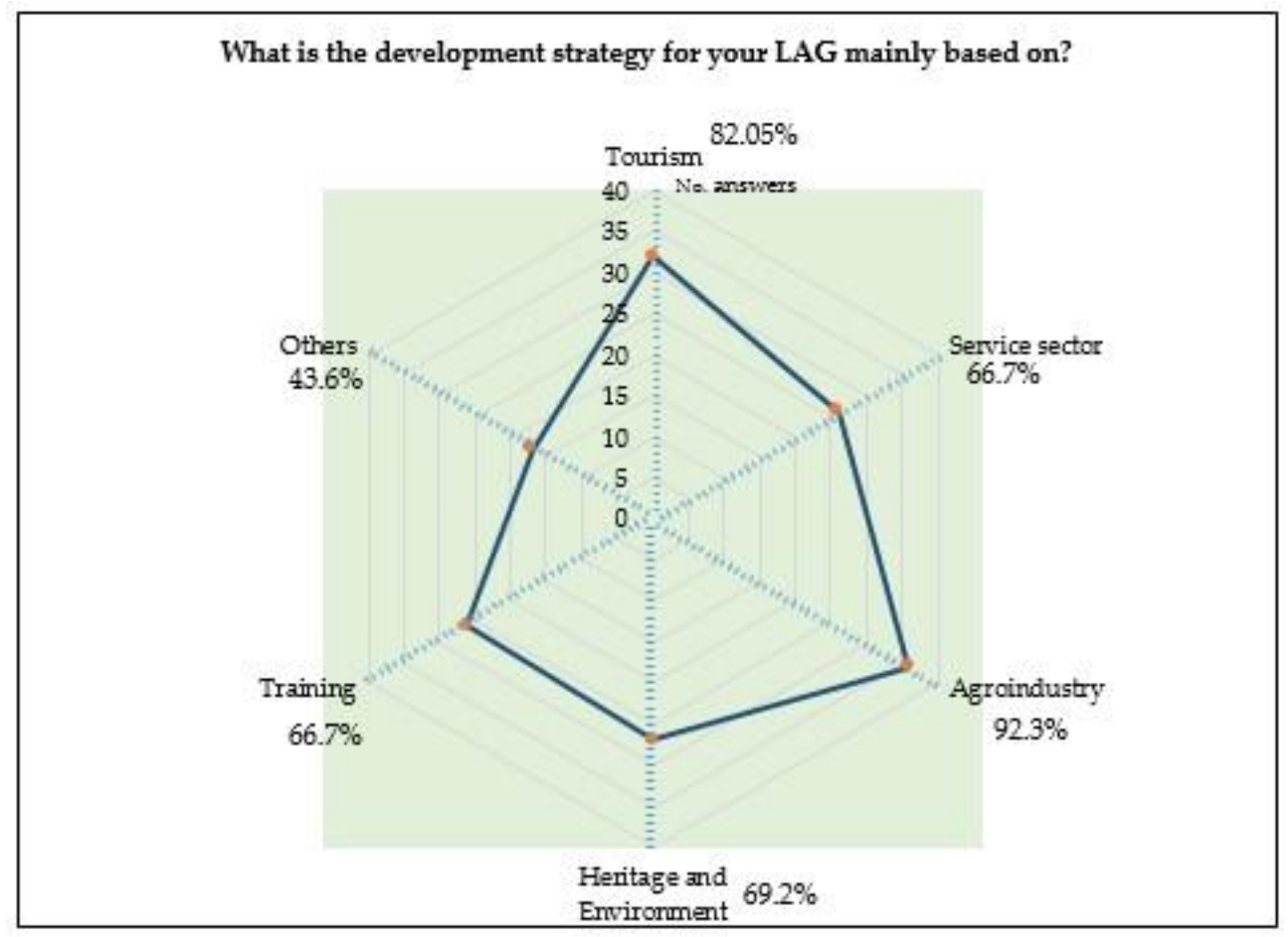

Fig 3. Answers to the question about the sectors on which the development strategy is based. 
According to the results in the question of whether it was difficult to find promoters in the smallest municipalities of the LAG, $89.4 \%$ of the respondents considered that they did have difficulties. For this reason, expectations regarding the achievement of this objective may be low, due to the continuous and increasingly pressing economic and demographic problems experienced by rural areas (lack of a dynamic economic fabric and young population). Of the residents who have been involved in development processes (Figure 4) and who have opted to invest in rural areas, $89.4 \%$ are small self-employed and $69.2 \%$ are medium-sized entrepreneurs; on the other hand, $33 \%$ are cooperatives and $20.5 \%$ are associations. Big businessmen do not receive any response, but it must be borne in mind that Extremadura has few great companies and that, as is logical, they generally do not require this type of aid. In addition, the maximum amount of public co-financing for projects managed with LEADER cannot exceed 200,000 Euros (Nieto Masot \& Cárdenas Alonso, 2017a), which is why large entrepreneurs often opt to request other types of European aid or regional incentives.

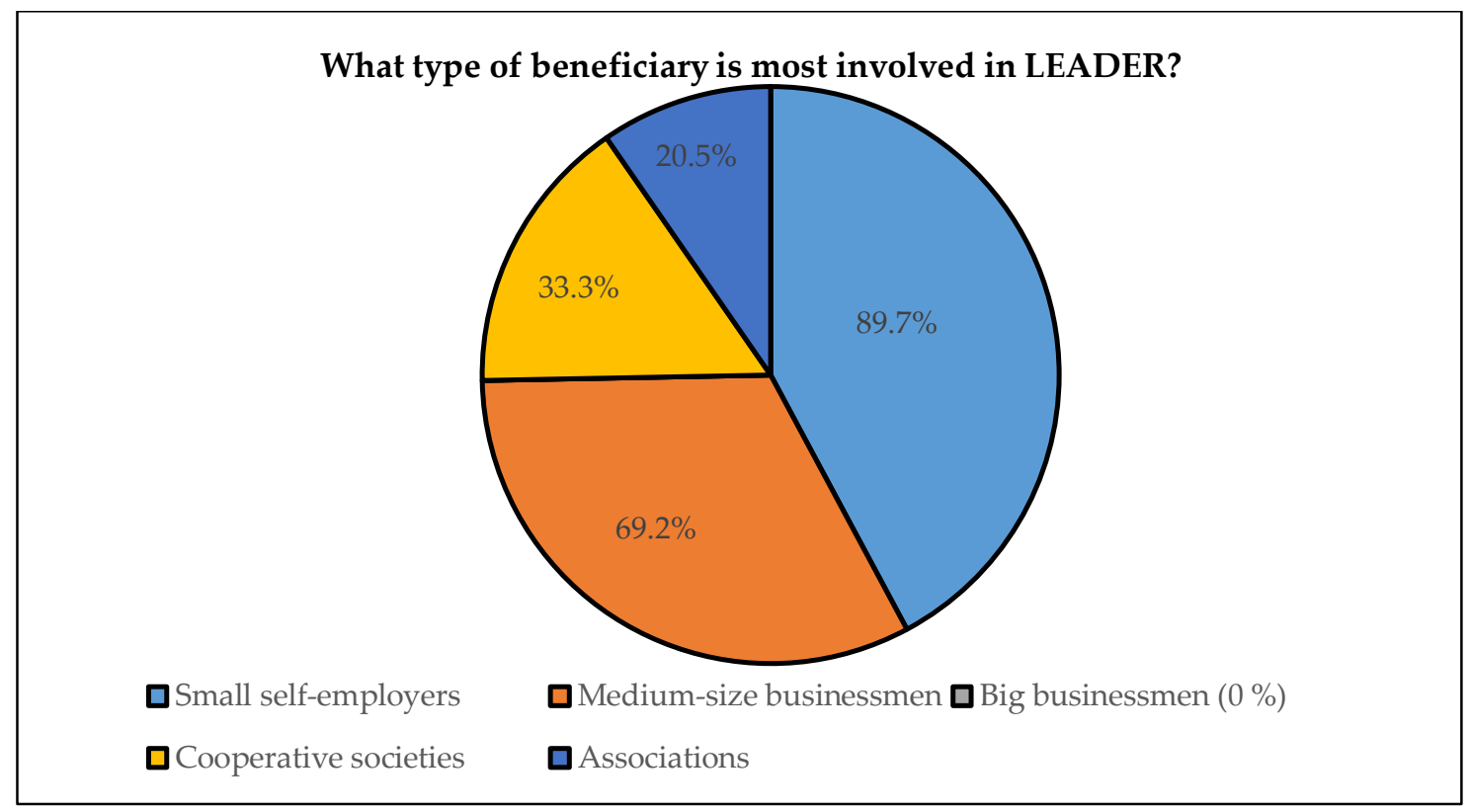

Fig 4. Answers to the question about the type of beneficiary involved in LEADER.

Regarding the influences of LEADER, all respondents believe that there have been many and generally positive. $28.2 \%$ consider that the impulse for endogenous and sustainable development of their areas of action through LEADER has been very high, and a large part (48.7\%), high, while $23 \%$ simply medium.

One of the main objectives pursued with LEADER is the economic diversification of rural areas and $79.5 \%$ of those surveyed consider that this is being achieved in Extremadura and in a positive way. It has contributed, above all, to the development of tourist activities $(76.9 \%$ of the responses), which coincides with the objectives of a large number of LAGs, especially in the most economically and demographically disadvantaged rural areas of Extremadura but with rich natural and historical resources, and service sector (69.2\%) (Figure 5). However, regarding the economic impact, the majority $(76.5 \%)$ believe that it has not contributed to the increase in the incomes of the municipalities of their LAGs, although it contributes to a slight maintenance of the population (84.6\%). This can be contradictory, since most of the population settles in those places that offer, generally, greater economic, but also social, welfare. The respondents highlight this, since $97.4 \%$ think that, thanks to LEADER, the social welfare of their municipalities has been improved by investing in tertiary services, cultural, sports and educational infrastructures and, to a lesser extent, in other basic services as improvement of public lighting or sidewalks. Obviously, all these public services do not imply a great economic enrichment of the population but rather the quality of life. 


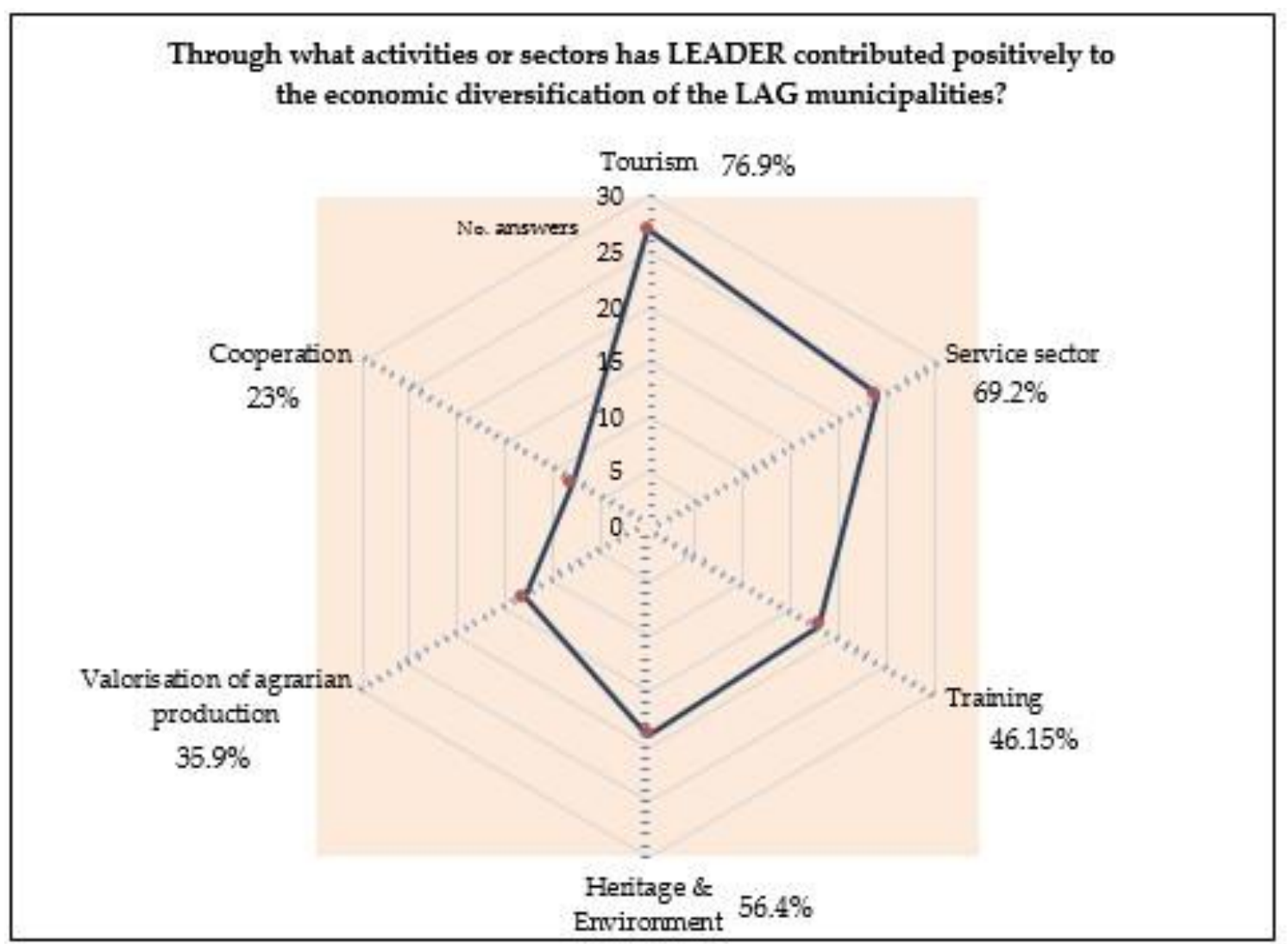

Fig 5. Answers to the question about the contribution of activities in the economic diversification.

Regarding the environmental aspect, the respondents also consider that the work of LEADER is paying off, since $88 \%$ think that the projects dedicated to the conservation and improvement of spaces and natural resources are being very adequate and are improving the conditions of life of their territories. Furthermore, it is important that 38 of the 39 respondents believe that LEADER is helping to strengthen the identity of the LAG.

If there is something that characterizes the 2007-2013 Programming Period, it is its changes in terms of Regulations, operation and management of aid compared to previous periods. These changes have resulted in greater administrative and bureaucratic procedures that have negatively conditioned the dynamic work of the LAGs. All respondents believe that, due to the above, the EAFRD has been launched with numerous difficulties and delays, which, consequently, has conditioned the development of numerous committed projects. $97.5 \%$ also indicate that their LAGs have been affected by the economic crisis, although $33.3 \%$ do not believe that the number of projects has decreased significantly compared to previous periods. In fact, the number of projects has increased in some more dynamic territories and with a stronger business fabric, such as Vegas Altas del Guadiana or areas close to the urban centers of the region. It is true that, unfortunately, the municipalities that have always presented the worst demographic and economic situations are those in which traditionally fewer projects and of lesser economic magnitude have developed, so the impact has not been so noticeable. $64.1 \%$ of the respondents stated that, due to all the problems, their LAGs have had difficulty adjusting to the budgets expected and committed at the beginning of the program. As for the reasons why it has occurred, the vast majority (79.3\%) think that it is due to the economic crisis, $13 \%$ due to the disillusionment of the population and possible promoters and $6.9 \%$ due to the exhaustion of the influence of LEADER in Extremadura.

The final distribution of aid has largely depended on all of the above. In this way, $84.6 \%$ believe that there is a clear tendency to invest, with LEADER, towards the same activity area. Regarding the territorial distribution, $48.7 \%$ consider that the location of the RDC (Rural Development Centre) has influenced and contributed to a greater location of projects and activities in the county 
seat, where it is usually located. However, $51.3 \%$ think the opposite, which is no, being a percentage that increases $(74.3 \%)$ when they are asked if they believe that the distribution of aid may be experiencing positive discrimination towards the most developed and more populated municipalities. A large part (64.1\%) also do not believe that a concentration of aid is being experienced in the most developed LAGs in Extremadura, although the quantitative data analyzed in previous studies (Cárdenas Alonso \& Nieto Masot, 2017; Nieto Masot \& Cárdenas Alonso, 2015, 2018; Nieto Masot et al., 2019) do not show these results.

Lastly, the questionnaire ended with an open question on which to express considerations that respondents thought appropriate about the application and operation of LEADER during the 2007-2013 period in Extremadura. These are some of the opinions collected:

"It is necessary and essential to reduce the bureaucratic burden of rural development programs and redirect the role of the LAG to what it was initially, that is, to a dynamic agent that encourages and accompanies the protagonists of the projects. It is also important to avoid the role of aid inspector that has been assigned to us in recent times".

"In this case, the major disadvantage for promoters requesting LEADER aids is the volume of documentation that we request for the processing file. Moreover, it is interesting to create a financial instrument that supports the entrepreneur in financing the aid reference project until the moment of receiving the money".

"Administrative obstacles are an important problem for entrepreneurs, since, in some cases, they are forced to give up aid due to not being able to obtain permits, licenses, etc. within the established period. Another problem has been the lack of financing by banks. Likewise, the figure of local development agents is necessary in order to help promoters in the drafting and presentation of their aid files".

"Rural development programs have as a priority objective to avoid the depopulation of small municipalities. In Extremadura, during the 2007-2013 period, the distribution of funds has not been correct, since large population centers have accessed them without really needing them. This has diminished the possibility of development of other municipalities that are more at risk of depopulation".

As can be seen in Figure 6 and Table 2, in the analysis of the opinions of the respondents, the most frequently mentioned word is necessary, followed by administrative and derived words. Through the results, it can be deduced that the respondents agree, above all, on the existence of needs in their territories and issues related to technical and administrative aspects. Furthermore, they identify responsibilities of the administration, as well as the need for greater funds and deadlines, and less bureaucracy.

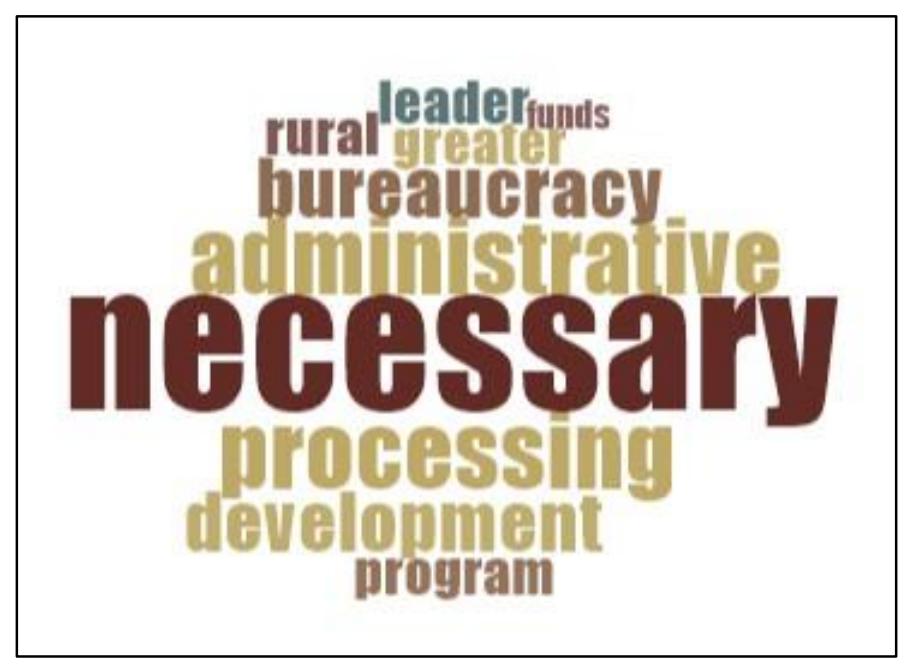

Fig 6. Word cloud. Source: Authors based on the opinions of LAGs staffs and NVIVO Pro 11 
Tab 2. Word frequency. Source: Authors based on the opinions of LAGs staffs and NVIVO Pro 11

\begin{tabular}{|l|c|c|}
\hline \multicolumn{1}{|c|}{ Word } & Count & Weighted percentage \\
\hline Necessary & 11 & 3.10 \\
\hline Administrative & 7 & 1.97 \\
\hline Processing & 7 & 1.97 \\
\hline Bureaucracy & 6 & 1.69 \\
\hline Development & 6 & 1.69 \\
\hline Greater & 5 & 1.41 \\
\hline LEADER & 5 & 1.41 \\
\hline Program & 5 & 1.41 \\
\hline Rural & 5 & 1.41 \\
\hline Funds & 4 & 1.13 \\
\hline
\end{tabular}

The ideas extracted from the word cloud are reinforced with the tree that relates them (Figure 7). The technicians and managers agree that it is necessary to reduce and simplify the bureaucratic burdens in the management of LEADER projects so that they can help promoters and entrepreneurs in accordance with the programs and development strategies designed by the LAGs, as well as in a balanced way between some territories and others.

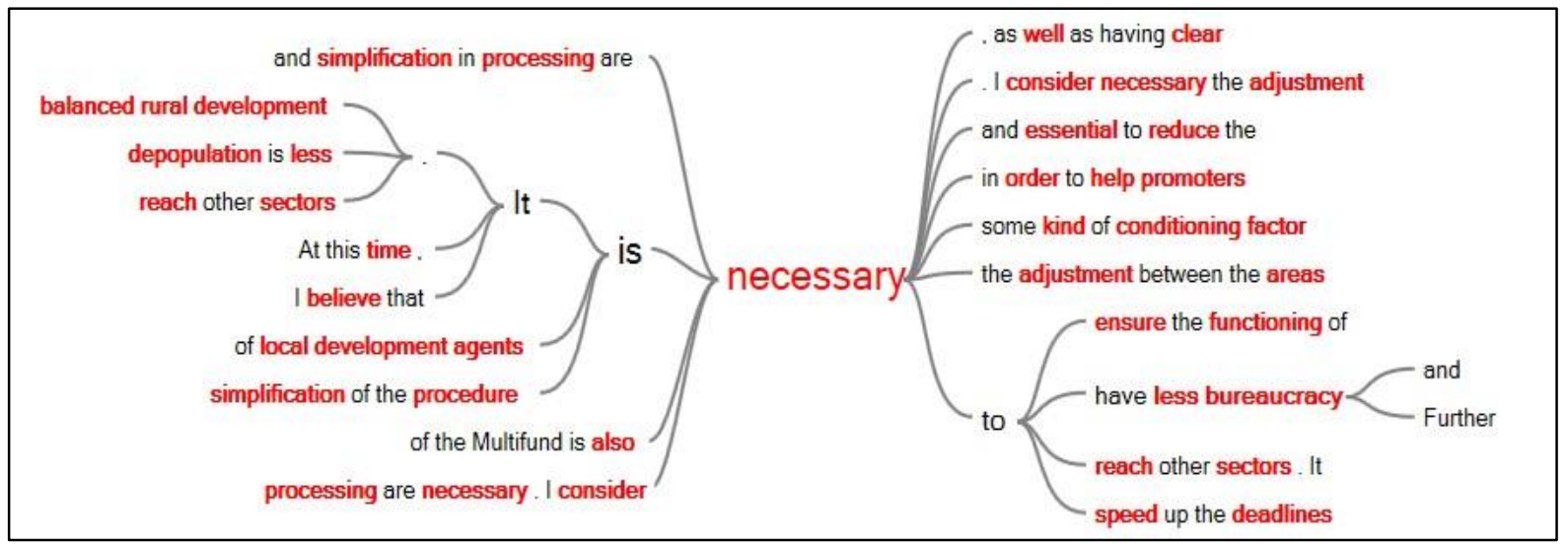

Fig 7. Word tree. Source: Authors based on the opinions of LAGs staffs and NVIVO Pro 11

\section{Discussion and Conclusion}

Through the analysis of the answers to the questionnaire completed by workers from the LAGs of Extremadura, it has been possible to extract a series of reflections on the operation of LEADER in Extremadura. This would not have been possible from only the quantitative data on investments and projects. In this way, the objective presented initially is achieved, that is, to complement the existing studies and present ideas until now little published about LEADER in Extremadura, that is, ideas about intangible aspects in development and governance processes in rural Extremadura.

Regarding the method chosen in this research, it is believed that it is appropriate, in fact, authors such as Yin (2015) argues that qualitative research tools like conducting interviews can improve the understanding of the information provided by the interviewee by allowing interaction and for an adequate contextualization of their opinions. Furthermore, this paper is supported by other studies (Cheevapattananuwong, Baldwin, Lathouras, \& Ike, 2020; de Castro-Pardo, PérezRodríguez, Martín-Martín, \& Azevedo, 2019; Vecchio, Iddrisu, Adinolfi, \& De Rosa, 2020; Vukomanovic, Skrip, \& Meentemeyer, 2019) that have resorted to the same methodology to study aspects related to the relevance that local people's participation and social capital can acquire in development processes. 
In general, the reply of the LAGs has been adequate, they have answered to a greater or lesser degree, although a greater number of responses could have been obtained. In addition, the usefulness of the questionnaire for a qualitative analysis is clear, being, in addition, a tool that makes it possible to compare the application of LEADER in other territories and through other groups. In future research, the aim is to send a similar questionnaire to businessmen who are beneficiaries of some of the LEADER subsidies, as well as to the local population, in order to have a more complete vision of the qualitative impact of the rural development aid in Extremadura. Thus, the LAGs of the region trust their work and that it is being done adequately, however, some of their considerations are pessimistic, mainly due to the role that administration is playing.

LEADER results, according to respondents, are paying off. From the economic point of view, a diversification of activities is being achieved decoupling the economy of rural areas from the agrarian sector, betting, above all, on tourism and the activities related to it, and on the service sector. However, they do not consider that the final economic impact is so noticeable, especially on incomes, mainly due to the shortage of funds managed by LEADER (public financing cannot exceed 200,000 euros). Thus, they believe that the impact is being mainly social, by financing non-productive projects that favor the improvement of living conditions and the environment of their municipalities and, also, the involvement of the population in development processes and that it is increasingly proud to belong to its county.

However, for the LAGs, the entire positive that LEADER is achieving in Extremadura would be greater and better if the operation, in terms of administrative management, changes. The bureaucratic and administrative pressure that LAG workers feel is clear and they believe that efforts should focus more on providing greater financial resources and greater freedom in their work in aid management. The objective is to be able to act as dynamizing agents with the population as in the early days of LEADER and to become aware of the economic and sociodemographic situation. Moreover, they purport to form networks of actors truly involved in development processes in order to define a common project in function of the image that they themselves have about their present and their future. For example, the work of the LAGs and their workers as specialists of the territory on which they act is vital to analyze and try to solve problems such as depopulation. Through the LAGs, both representatives of public administrations and businessmen, agrarian organizations or neighbors, can debate and offer solutions based on the propositions made by the local population, which is what should finally want to establish their residence in rural areas.

In the case of works on other European regions, the results are similar. Chevalier et al. (2017) are critical of the excessive regulation introduced in the latest editions of the LEADER Initiative and consider that this has distorted the original principles of this Initiative. Furthermore, the same authors, analysing the application of the LEADER approach in different European regions, detects a tendency of local elites, in this case municipal politicians, trying to monopolise the LAGs' decision-making process. These conclusions are shared by Esparcia et al. (2000), who showed the tensions that have arisen in the articulation of the LAGs given the interest of different groups in taking control of decision-making.

In our work, it can be seen how respondents think that the influence that institutional presence has on the management systems of the LEADER approach is determinant, this being a result also supported by Bruckmeir's studies (2000) on LEADER in Germany.

Castellano et al. (2020), in a research on La Vera (Extremadura), support analyzing the opinion of the LAG technical teams, since, to a certain extent, their effort depends on something "intangible", on a human component that must be measured and analyze through, as they also do, the elaboration of questionnaires and their qualitative analysis.

The positive general assessment provided by the LAGs of Extremadura in this study seems logical. However, it should perhaps be borne in mind that the success of current rural development is based on the complementarity between the traditional top-down approach of the Administration and the modern bottom-up of the public-private partnerships that LAGs are. The first is necessary to guarantee a regulation and stable financing, and the second, not so much to create new companies and equipment or infrastructures, but to give vitality to rural areas associating 
the achievements with the needs of the population and involving it in development processes in order to stop the aging and depopulation problems experienced by rural areas.

\section{Acknowledgments}

It is gratefully acknowledged the collaboration of Local Action Groups of Extremadura, as well as of ERDF (European Regional Development Fund) and Government of Extremadura (Spain), which funded this research (Grant number GR18052).

\section{Academic references}

[1] Abad Aragón, L. D. (2013). Territorio, cooperación y desarrollo: la iniciativa europea leader como modelo de gobernanza en espacios periurbanos: dos casos de estudio en la Comunidad de Madrid: las comarcas de la Sierra Norte y de las Vegas. Universidad Complutense de Madrid.

[2] Abad Aragón, L. D. (2014). Gobernanza en espacios periurbanos a través de la iniciativa europea LEADER. El caso de la Comarca madrileña de Las Vegas. Anales de Geografia de la Universidad Complutense, 34(1), 23.

[3] Alario, M. \& Baraja, E. (2006). Políticas públicas de desarrollo rural en Castilla y León: ¿Sostenibilidad consciente o falta de opciones? LEADER II. Boletin de la Asociacion de Geografos Espanoles 41, 267-294.

[4] Alfaro, J., Mondéjar, J., Vargas, M. (2004). Análisis del impacto de los programas LEADER y PRODER en Castilla-La Mancha: medidas de apoyo a pequeñas empresas, artesanía y servicios. Revista de Desarrollo Rural y Cooperativismo agrario 8, 63-75.

[5] Álvarez Gómez, J. (1999). El asociacionismo e innovación como ejes del desarrollo: La iniciativa LEADER en el ámbito rural. REVESCO: revista de estudios cooperativos 68, 67-74.

[6] Arribas, M. (2004). Diseño y validación de cuestionarios. Matronas profesión 5(17), 23-29.

[7] Bjärstig, T. \& Sandström, C. (2017). Public-private partnerships in a Swedish rural contextA policy tool for the authorities to achieve sustainable rural development? Journal of Rural Studies, 49, 58-68. DOI: 10.1016/j.jrurstud.2016.11.009.

[8] Bruckmeier, K. (2000). LEADER in Germany and Discourse of Autonomous Regional Development. Sociologia Ruralis, 40(2), 219-227. DOI: 10.1111/1467-9523.00144.

[9] Buciega, A. \& Esparcia, J. (2013). Desarrollo, Territorio y Capital Social. Un análisis a partir de dinámicas relacionales en el desarrollo rural. Redes. Revista hispana para el análisis de redes sociales 24(1), 81-113. DOI: 10.5565/rev/redes.350.

[10] Buciega Arévalo, A. (2012). Capital social y LEADER. Los recursos generados entre 1996 y 2006. AGER 14, 111-144.

[11] Buller, H. (2002). Re-Creating Rural Territories: LEADER in France. Sociologia Ruralis, 4O(2), 190-199. DOI: 10.1111/1467-9523.00141.

[12] Cárdenas Alonso, G. \& Nieto Masot, A. (2017). Towards Rural Sustainable Development? Contributions of the EAFRD 2007-2013 in Low Demographic Density Territories: The Case of Extremadura (SW Spain). Sustainability, 9(7), 1173. DOI: 10.3390/su9071173.

[13] Cárdenas Alonso, G. \& Nieto Masot, A. (2020). El Enfoque LEADER en el nuevo FEADER 2014-2020 en Extremadura Cuadernos Geograficos, 59(2), 5-26. DOI: $10.30827 /$ cuadgeo.v59i2.9384.

[14] Carmona García, F. J. (2013). Analisis territorial de los efectos de los programas de desarrollo rural LEADER+ y PRODER II en Castilla-La Mancha. Ciudad Real: Universidad de Castilla-La Mancha. 
[15] Castellano-Álvarez, F. J., Nieto Masot, A. \& Castro-Serrano, J. (2020). Intangibles of Rural Development. The Case Study of La Vera (Extremadura, Spain). Land, 9(6), 203. DOI: $10.3390 /$ land9060203.

[16] Cejudo, E. \& Navarro, F. A. (2009). La inversión en los programas de desarrollo rural. Su reparto territorial en la provincia de Granada. Anales de Geografia de la Universidad Complutense, 29(2), 27.

[17] Cortés Macías, R. (2001). El desarrollo rural en Andalucía a través de la iniciativa LEADER y los programas PRODER. Baetica(23), 12.

[18] Cheevapattananuwong, P., Baldwin, C., Lathouras, A. \& Ike, N. (2020). Social Capital in Community Organizing for Land Protection and Food Security. Land, 9(3), 69. DOI: $10.3390 /$ land9030069.

[19] Chevalier, P., Mačiulyté, J., Razafimahefa, L. \& Dedeire, M. (2017). European Countryside, 9(2), 317-341. DOI: 10.1515/euco-2017-0020.

[20] Dax, T. \& Fischer, M. (2018). An alternative policy approach to rural development in regions facing population decline. European Planning Studies, 26(2), 297-315. DOI: 10.1080/09654313.2017.1361596.

[21] de Castro-Pardo, M., Pérez-Rodríguez, F., Martín-Martín, J. M. \& Azevedo, J. C. (2019). Planning for Democracy in Protected Rural Areas: Application of a Voting Method in a Spanish-Portuguese Reserve. Land, 8(10), 145. DOI: 10.3390/land8100145.

[22] Delgado, M. T., Ramos, E., Gallardo, R. \& Ramos, F. (1999). De las nuevas tendencias en la evaluación a su aplicación en las iniciativas Europeas de desarrollo rural. In Ramos, E.C., ed., El desarrollo rural en la Agenda 2000 (pp. 321-344). Madrid: Ministerio de Agricultura, Pesca y Alimentacion.

[23] Delgado Viñas, C. (2002). Los Programas de Desarrollo Rural en Cantabria. Libro Blanco de la Agricultura y el Desarrollo Rural. Madrid: Ministerio de Agricultura, Pesca y Alimentacion.

[24] Delgado Viñas, C. \& Fuente Royano, M. T. (2000). Las diferentes formas de abordar el desarrollo rural desde el PRODER: los ejemplos de Cantabria. In García Pascual, F. (Coord). El mundo rural en la era de la globalitación: incertidumbres y potencialidades $X$ Coloquio de Geografía Rural. Madrid, Ministerio de Agricultura, Pesca y Alimentación. Serie Estudios, Universitat de Lleida, 650-662.

[25] Esparcia, J., Escribano, J. \& Buciega, A. (2015). A perspective of LEADER Method in Spain based on the Analysis of Local Action Groups. In Granberg, L. \& Andersson, K., eds., Evaluating the European Approach to Rural Development: Grass-roots Experiences of the LEADER Programme (pp. 33-51). London: Routledge.

[26] Esparcia Pérez, J., Noguera Tur, J. \& Pitarch Garrido, M. D. (2000). LEADER in Spain: Rural development, power, legitimation, learning and new structures. Documents d'Analisi Geografica 37, 95-113.

[27] Febles Ramírez, M. F., García Rodríguez, J. L. \& Zapata Hernández, V. M. (2005). La iniciativa comunitaria LEADER en España. Boletin de la Asociacion de Geografos Espanoles 39, 361-398.

[28] Fernández, S. F., Sánchez, J. M. C., Córdoba, A. \& Largo, A. C. (2002). Estadística descriptiva. Madrid: Esic Editorial.

[29] Foddy, W. \& Foddy, W. H. (1994). Constructing questions for interviews and questionnaires: Theory and practice in social research. Cambridge University Press.

[30] Garrido Fernández, F. E. \& Moyano Estrada, E. (2002). Capital social y desarrollo en zonas rurales: Un análisis de los programas Leader II y Proder en Andalucía. Revista internacional de sociología 60(33), 67-96. 
[31] Gómez Borja, M. A., Mondéjar Jiménez, J., Mondéjar Jiménez, J. A. \& Monsalve Serrano, F. (2006). El turismo rural en los programas de desarrollo en Castilla-La Mancha. In Blanquer, D., ed., Espacios rurales: $8^{\circ}$ Congreso de Turismo. Universidad y empresa (pp. 483-502). Valencia: Tirant Lo Blanch.

[32] Grybovych, O. \& Hafermann, D. (2010). Sustainable practices of community tourism planning: Lessons from a remote community. Community Development, 41(3), 354-369. DOI: 10.1080/15575330903444085.

[33] Kovach, I. (2000). LEADER, a new social order, and the Central-and East-European Countries. Sociologia Ruralis, 40(2), 181-189. DOI: 10.1111/1467-9523.00140.

[34] Leco Berrocal, F., Pérez Díaz, A. \& Mateos Rodríguez, A. B. (2017). Crisis demográfica en la Extremadura rural: valoración a través de los Grupos de Acción Local (2007-2014). Cuadernos Geograficos, 56(1), 76-100.

[35] Lemus Martín, S. D., Castillo, M., Moya Morales, M. C., Padilla García, J. L. \& Ryan, E. (2008). Elaboración y validación del Inventario de Sexismo Ambivalente para Adolescentes. International Journal of Clinical and Health Psychology 8(2), 537-562.

[36] Lenao, M. \& Saarinen, J. (2015). Integrated rural tourism as a tool for community tourism development: exploring culture and heritage projects in the North-East District of Botswana. South African Geographical Journal 97(2), 203-216. DOI: 10.1080/03736245.2015.1028985.

[37] Long, F. J. \& Arnold, M. B. (1995). The power of environmental partnerships: San Diego, CA: Harcourt College Pub.

[38] Los Ríos-Carmenado, D., Cadena-Iñiguez, J. \& Díaz-Puente, J. M. (2011). Creación de grupos de acción local para el desarrollo rural en México: Enfoque metodológico y lecciones de experiencia. Agrociencia, 45(7), 815-829.

[39] Márquez Fernández, D., Foronda Robles, C., Galindo Pérez de Azpillaga, L. \& García López, A. (2005). Eficacia y eficiencia de Leader II en Andalucía. Aproximación a un índice-resultado en materia de turismo rural. Geographicalia 47, 137-152.

[40] Martín Cilleros, M. V. \& Sánchez Gómez, M. C. (2016). Análisis cualitativo de tópicos vinculados a la calidad de vida en personas con discapacidad. Ciencia \& Saude Coletiva, 21, 2365-2374. DOI: 10.1590/1413-81232015218.04182016.

[41] Mondéjar Jiménez, J., Mondéjar Jiménez, J. A., Monsalve Serrano, F. \& Vargas Vargas, M. (2007). Una propuesta de evaluación del impacto de los programas de desarrollo rural LEADER y PRODER. AGER 6, 161-180.

[42] Munn, P. \& Drever, E. (1990). Using Questionnaires in Small-Scale Research. A Teachers' Guide. Edinburgh: Scottish Council for Research in Education.

[43] Navarro, F., Cejudo, E. \& Maroto, J. C. (2014). Reflections on participation in rural development. Social distribution or strengthening of power? LEADER and PRODER in southern Spain. Eure 40(121), 75-91.

[44] Navarro, F., Woods, M. \& Cejudo, E. (2015). The LEADER Initiative has been a Victim of Its Own Success. The Decline of the Bottom-Up Approach in Rural Development Programmes. The Cases of Wales and Andalusia. Sociologia Ruralis 56(2), 270-288. DOI: $10.1111 /$ soru.12079.

[45] Nieto Masot, A. \& Cárdenas Alonso, G. (2015). El Método LEADER como política de desarrollo rural en Extremadura en los último 20 años (1991-2013). Boletin de la Asociacion de Geografos Espanoles 69. DOI: 10.21138/bage.1893.

[46] Nieto Masot, A. \& Cárdenas Alonso, G. (2017a). 25 Years of the LEADER Initiative as European Rural Development Policy: The Case of Extremadura (SW Spain). European Countryside, 9(2), 302-316. DOI: 10.1515/euco-2017-0019. 
[47] Nieto Masot, A. \& Cárdenas Alonso, G. (2017b). Análisis del Método LEADER (2007-2013) en Extremadura mediante técnicas SIG y Análisis Multivariado. Cuadernos Geograficos 56(1), 148-171.

[48] Nieto Masot, A. \& Cárdenas Alonso, G. (2018). The Rural Development Policy in Extremadura (SW Spain): Spatial Location Analysis of Leader Projects. ISPRS International Journal of Geo-Information 7(2), 76. DOI: 10.3390/ijgi7020076.

[49] Nieto Masot, A., Cárdenas Alonso, G. \& Costa Moreno, L. M. (2019). Principal Component Analysis of the LEADER Approach (2007-2013) in South Western Europe (Extremadura and Alentejo). Sustainability 11(15), 4034. DOI: 10.3390/su11154034.

[50] Nieto Masot, A., Cárdenas Alonso, G. \& Engelmo Moriche, A. (2020). Spatial analysis of the rural-urban structure of the Spanish municipalities. ISPRS International Journal of GeoInformation, 9(4), 213. DOI: 10.3390/ijgi9040213.

[51] Osti, G. (2000). LEADER and Partnerships: The Case of Italy. Sociologia Ruralis, 40(2), 9. DOI: 10.1111/1467-9523.00139.

[52] Palacios Vicario, B., Gutiérrez García, A. \& Sánchez Gómez, M. C. (2013). NVIVO una herramienta de utilidad en el mundo de la comunicación. In Mariño, M. V., Gonzáles Hortigüela, T. \& Pacheco Rueda, M., eds., Investigar la Comunicación hoy. Revisión de políticas científicas y aportaciones metodológicas (pp. 1003-1018). University of Valladolid.

[53] Pérez, J. A. (2007). Los intangibles en el desarrollo rural. Cáceres: Universidad de Extremadura.

[54] Quaranta, G., Citro, E. \& Salvia, R. (2016). Economic and social sustainable synergies to promote innovations in rural tourism and local development. Sustainability, 8(7), 668. DOI: $10.3390 /$ su8070668.

[55] Ray, C. (1999a). Endogenous development in the era of reflexive modernity. Journal of Rural Studies 15(3), 257-267. DOI: 10.1016/S0743-0167(98)00072-2.

[56] Ray, C. (1999b). Towards a Meta-Framework of Endogenous Development: Repertoires, Paths, Democracy and Rights. Sociologia Ruralis, 39(4), 522-537. DOI: 10.1111/14679523.00122.

[57] Risco Rosales, I. \& De la Macorra Cano, L. F. (2006). Área transfronteriza Alentejo, Extremadura y Centro: situación socioeconómina y perspectivas. Revista de Estudios Extremeños, 62(3), 1145-1166.

[58] Rizzo, F. (2013). LEADER Policy practices and landscapes in the light of the agencystructure debate: evidence from LEADER Local Action Groups in Italy and in Finland. European Countryside 5(3), 232-250. DOI: 10.2478/euco-2013-0015.

[59] Rosado, M. C. (2006). Extremadura y Alentejo: Del subdesarrollo heredado a los retos del futuro. Revista de Estudios Extremeños, 62(3), 1167-1188.

[60] Sáenz Lorite, M. \& Cejudo García, E. (2008). La Política de Desarrollo Rural de la Unión Europea para 2007-2013. Investigaciones geográficas(46), 5-30.

[61] Sancho Comíns, J. \& Reinoso Moreno, D. (2012). La delimitación del ámbito rural: una cuestión clave en los programas de desarrollo rural. Estudios Geograficos, 73(273), 599624. DOI: 10.3989/estgeogr.201221.

[62] Sarasola Sánchez-Serrano, J. L., López Meneses, E. \& Fernández Márquez, E. (2013). Experiencias de posgrado sobre el envejecimiento a través de nubes de palabras. Didáctica, innovación y multimedia 25, 1-13.

[63] Saz-Gil, M. I. \& Gómez-Quintero, J. D. (2015). Una aproximación a la cuantificación y caracterización del capital social: una variable relevante en el desarrollo de la provincia de Teruel, España. EURE (Santiago), 41(123), 29-51. DOI: 10.4067/S025071612015000300002. 
[64] Shucksmith, M. (2000). Endogenous development, social capital and social inclusion: Perspectives from LEADER in the UK. Sociologia Ruralis, 40(2), 208-218. DOI: 10.1111/1467-9523.00143.

[65] Shucksmith, M. (2004). Young people and social exclusion in rural areas. Sociologia Ruralis, 44(1), 43-59. DOI: 10.1111/j.1467-9523.2004.00261.x.

[66] Shucksmith, M. (2010). Disintegrated Rural Development? Neo-endogenous Rural Development, Planning and Place-Shaping in Diffused Power Contexts. Sociologia Ruralis, 50(1), 1-14. DOI: 10.1111/j.1467-9523.2009.00497.x.

[67] Trigueros Cervantes, C., Rivera García, E., Moreno Doña, A. \& Muñoz Luna, R. (2016). Uso del software CAQDAS Nvivo en Ciencias Sociales para la investigación con grupos de discusión. Index de Enfermería, 25(3), 171-174.

[68] Van Huijstee, M. M., Francken, M. \& Leroy, P. (2007). Partnerships for sustainable development: a review of current literature. Environmental Sciences, 4(2), 75-89. DOI: $10.1080 / 15693430701526336$.

[69] Vargas-Vargas, M., Meseguer-Santamaría, M. L., Mondéjar-Jiménez, J. \& MondéjarJiménez, J. A. (2009). Los Programas de Innovación rural en Castilla-La Mancha: Un análisis de la inversión en Pymes y Servicios. Papeles de Geografía, 49-50, 161-174.

[70] Vargas-Vargas, M., Mondéjar-Jiménez, J., Mondéjar-Jiménez, J.-A. \& MeseguerSantamaría, M.-L. (2009). European Grants For Investment In Regional SMEs: The Case Of Castilla-La Mancha (Spain). International Business \& Economics Research Journal, 8(4). DOI: 10.19030/iber.v8i4.3129.

[71] Vargas Vargas, M. \& Mondéjar Jiménez, J. A. (2006). Análisis de la inversión de los Fondos Europeos para el Desarrollo rural en Castilla-La Mancha. Revista económica de Castilla-La Mancha 9, 189-238.

[72] Vázquez Cano, E., López Meneses, E. \& Fernánd-ez Márquez, E. (2016). Análisis diacrónico de la percepción del estudiantado sobre la sociedad de la información con software social. Didáctica, innovación y multimedia 34, 1-11.

[73] Vecchio, Y., Iddrisu, A.-L., Adinolfi, F. \& De Rosa, M. (2020). Geographical Indication to Build up Resilient Rural Economies: A Case Study from Ghana. Sustainability, 12(5), 2052. DOI: 10.3390/su12052052.

[74] Vukomanovic, J., Skrip, M. M. \& Meentemeyer, R. K. (2019). Making it spatial makes it personal: engaging stakeholders with geospatial participatory modeling. Land, 8(2), 38. DOI: $10.3390 /$ land8020038.

[75] Yin, R. K. (2015). Qualitative research from start to finish: New York: Guilford publications.

[76] Zajda, K. (2014). Problems of functioning of Polish local action groups from the perspective of the social capital concept. Eastern European Countryside, 20(1), 73-97. DOI: 10.2478/eec-2014-0004.

\section{Other sources}

[77] Consejería de Medio Ambiente y Rural, P. A. y. T. (2020). DOTEX. Directrices de Ordenación Territorial de Extremadura. Avance. Mérida.

[78] Pemán, I. \& Jiménez, J. (2013). La Gobernanza multinivel como alternativa a la gestión del desarrollo del medio rural [unpublished report]. Diputación de Zaragoza. 